\title{
Segmentation in Agriculture and Farmers' Productivity: Evidence from Survey of Poultry Farms
}

\section{Joseph I Amuka ${ }^{\circledR \ltimes}(\mathbb{D}$ \\ Robinson I Nduaguba ${ }^{2}$ \\ Anthony $\mathbf{O} \mathrm{Agu}^{3}$ \\ Chinasa Urama ${ }^{4}$ \\ Bernadette C Onah ${ }^{5}$}
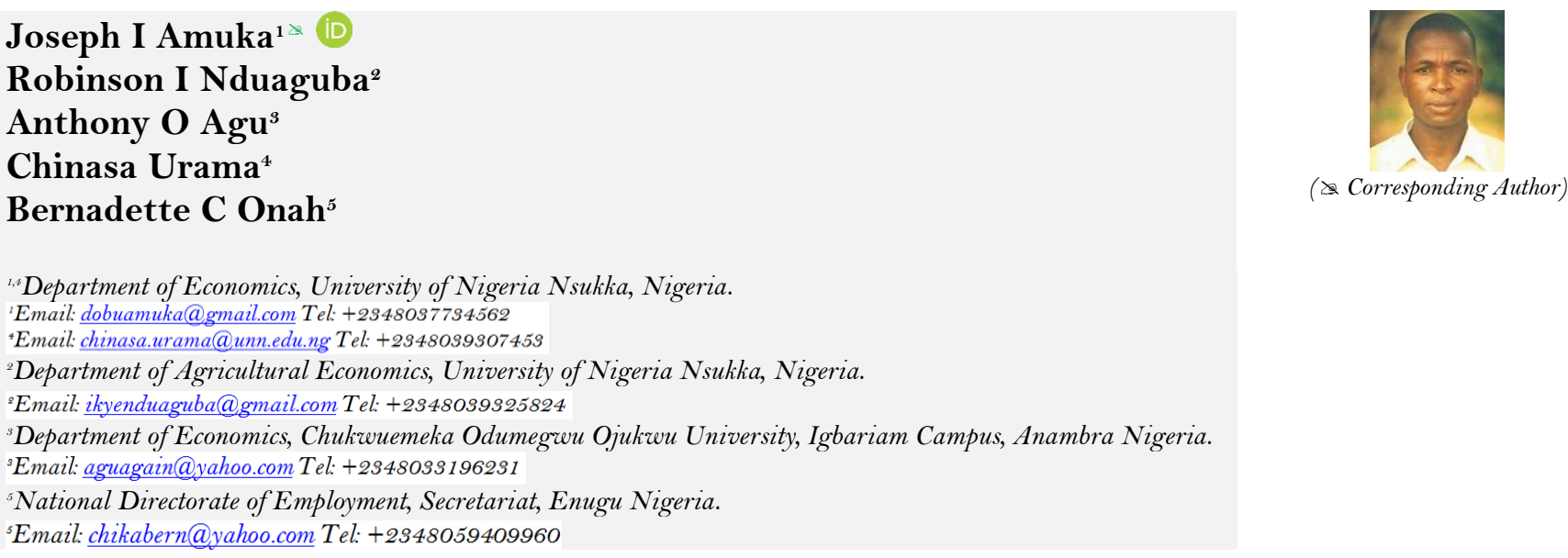

\section{Abstract}

The World Bank intervened in Nigeria agriculture in 2009 to increase productivity in 5 farm areas, namely-poultry, rice, maize, cashew and pineapple farming through the value chain strategy. Agricultural activity was segmented and farmers were encouraged to go into one farm operation only. Proponents of the segmentation argue that it holds the key to solving the low agricultural productivity in developing counties because farmers will only specialize in one farm area. That is, specialization will enable the farmer to innovates better ways of tackling problems, time the market and planting period to mitigate climate change. The aim of the research is to examine the effects of the segmentation practice on the productivity of Poultry farmers in Nigeria, using a survey data. Result from the survey using regression analysis did not support encouraging segmentation in poultry farming. This is because poultry farmers who engaged in more than one poultry practice had more yield of egg per bird. The lesson for agricultural policy is that farmers should be encouraged to engage in multiple farming practice.

Keywords: Segmentation, Agriculture, Productivity, Poultry, Farmers, Survey.

JEL Classification: Q1, Q12.

Citation | Joseph I Amuka; Robinson I Nduaguba; Anthony O Agu; Chinasa Urama; Bernadette C Onah (2020). Segmentation in Agriculture and Farmers' Productivity: Evidence from Survey of Poultry Farms. Asian Journal of Social Sciences and Management Studies, 7(1): 53-57.

History:

Received: 13 January 2020

Revised: 21 February 2020

Accepted: 25 March 2020

Published: 10 April 2020

Licensed: This work is licensed under a Creative Commons

Attribution 3.0 License $(\mathrm{cc}) \mathbf{E Y}$

Publisher: Asian Online Journal Publishing Group
Acknowledgement: All authors contributed to the conception and design of the study.

Funding: This study received no specific financial support.

Competing Interests: The authors declare that they have no conflict of interests.

Transparency: The authors confirm that the manuscript is an honest, accurate, and transparent account of the study was reported; that no vital features of the study have been omitted; and that any discrepancies from the study as planned have been explained.

Ethical: This study follows all ethical practices during writing.

\section{Contents}

1. Introduction.

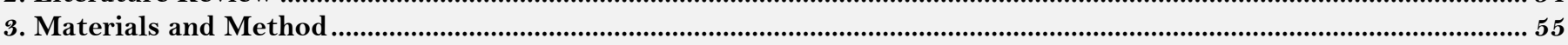

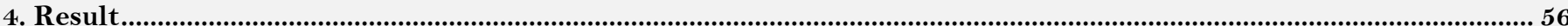

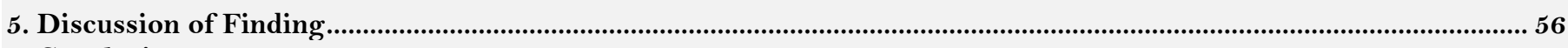

6. Conclusion ...

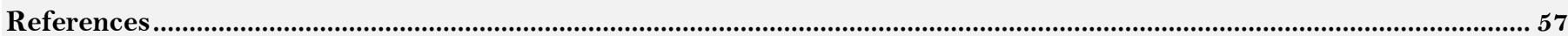




\section{Contribution of this paper to the literature}

The paper provided evidence that segmentation in agriculture is not the solution to low agricultural productivity in developing countries.

\section{Introduction}

Segmentation in agriculture system is a practice where every farm household engage in one agricultural activity at a time. It is a practice which allows a household to concentrates in one farm operation she feels she is more competitive. It is a shift from the multi farming system whereby a farm household can grow different crops or rear different types of animals and birds at a time. Segmentation in agriculture encourages specialization because the farmer is engaged in the same farm operation year in year out. Proponents of specialization argue that specialization has positive effect on productivity (Smith, 1776). According to Smith, doing one thing time without numbers makes a worker become familiar with his work and innovates better ways of handling problems.

Inquiry into low agricultural productivity in Africa and some other developing countries has been long. Unfortunately, agricultural productivity improved in Asia, South America and other continents but has continued to stagnate in Africa. Available statistics showed that rice yield in Africa rose from an average of $18835 \mathrm{hg} / \mathrm{ha}$ in 1971 to $25991 \mathrm{hg} / \mathrm{ha}$ in 2016. This is far from the yield in Asia which rose from $23811 \mathrm{hg} / \mathrm{ha}$ to $47545 \mathrm{hg} / \mathrm{ha}$, and the increase in South America from $16475 \mathrm{hg} / \mathrm{ha}$ to $54675 \mathrm{hg} / \mathrm{ha}$ within the same period (Food and Agricultural Organization (FAO), 2017a). Similarly, Africa lagged behind Asia and South America in the production of cassava which is one of Africa's favoured crops. In cassava production, average yield in Africa rose from $59991 \mathrm{hg} / \mathrm{ha}$ in 1971 to $92479 \mathrm{hg} / \mathrm{ha}$ in 2016. In the same vein, average yield in Asia rose from $93719 \mathrm{hg} / \mathrm{ha}$ to $213412 \mathrm{hg} / \mathrm{ha}$, and from $136600 \mathrm{hg} / \mathrm{ha}$ to $142162 \mathrm{hg} / \mathrm{ha}$ in South America within the same period.

At the country level, Nigeria suffers from fluctuating agricultural productivity. For example, cassava yield fell from $101911 \mathrm{hg} / \mathrm{ha}$ in 1971 to $91254 \mathrm{hg} / \mathrm{ha}$ in 2016 . However, yield in rice production rose slightly from 12763 $\mathrm{hg} / \mathrm{ha}$ in 1971 to $20265 \mathrm{hg} / \mathrm{ha}$ in 2016. Though, rice yield in Nigeria in 2016 was more than Africa average, the average yield in both rice and cassava in Nigeria was far below that of Asia and South America average in 2016. Rice and cassava feature prominently in the menu of Nigerians more than other food types. Nigeria population grew from 56,131844 in 1971 to 182,201962 in 2015, showing more than 300\% increase (World Bank, 2016). When we put this side by side with the $59 \%$ increase in rice yield and the $10 \%$ decline in the yield of cassava within the same period, the capacity of the country to meet the food needs of her population in future is in serious doubt.

In livestock production, egg yield per bird in Nigeria is one of the lowest among developing economies of the world. Egg yield per bird in Nigeria increased minimally from $4.17 \mathrm{~kg}$ in 1980 to $4.6 \mathrm{~kg}$ in 2014 . This was far below the increase in yield per bird in Oman and Panama within the same period. Egg yield per bird in Oman increased from $7.2 \mathrm{~kg}$ in 1980 to $14.53 \mathrm{~kg}$ in 2014. In Panama, egg yield per bird increased from $7.98 \mathrm{~kg}$ in 1980 to $13.79 \mathrm{~kg}$ in 2014 (Food and Agricultural Organization (FAO), 2017b). An explanation to the high disparity in agricultural productivity between Nigeria and her fellow developing countries has been discussed a long time ago. The problems ranged from low technology application to absence of processing facility, poor access to market, and lack of operational value chain (Awotide, Abdoulaye, Alene, \& Manyong, 2015; Awotide, Diagne, \& Omonona, 2012; Bassey, Edet, \& Agom, 2016).

Meat consumption is very important in the health of every human being because it supplies the body with the protein contents it requires to grow, repair and replace lost tissues. Egg from the bird is a veritable source of protein to the body and supplies the body with essential vitamins such as B2, B6, B12 and D, as well as minerals like Zinc, Iron and Copper. Fundamentally, egg contains essential ingredients the human body needs to grow healthy and perform daily work. Regrettably, egg and meat are luxury food in Nigeria because only very few households can afford the cost. It is because of the high cost of egg that compel greater number of Nigerians to fall back to plants for the protein needs of the body.

Segmentation model in agriculture was introduced in Nigeria in 2009 through the commercial agriculture development programme. The programme which was sponsored by the World Bank took off in five states in eight farm areas. The areas are Oil palm development, Cocoa, Rice, Fruit Trees (pineapple and cashew), Poultry, Maize, Dairy, and Aquaculture. The first phase of the programme ended in 2018 and government is trying to bring in more states into it. Past studies on the solutions to low agricultural productivity in Nigeria focused on improving financial access by the farmers (Awotide et al., 2015; Bassey et al., 2016), or making new technology available to farmers (Awotide et al., 2012). The aim of this study is to examine whether the segmentation in agriculture is better for increased productivity among the farmers in Nigeria. We are using the poultry sub-sector as the case study.

\section{Literature Review}

Improvement in agricultural productivity in developing countries has attracted national and international interest as well as interventions. Such models like financial access, technology improvement and extension services have been tried in efforts to mitigate the low productivity in agriculture in developing countries. Getting the required result is still challenging as the gap between yields in developed and developing countries remains very wide. In a shift of approach, strategy changed towards agricultural value chains in many of the developing countries including Nigeria. A value chain is the range of agricultural activities needed to ensure that agricultural commodities are delivered to the final consumers is an efficient way. Activities start from conception through intermediaries until the commodities reach the final consumer (Okike, 2010). It incorporates all activities and services that are undertaken along a commodity system from primary producer to the final consumer (Federal Ministry of Agriculture Water Resources and Rural Development, 2009).

Major actors in a value chain are farmers, assemblers/traders, processors, wholesalers, retailers, consumers and input suppliers. The major benefit of value chain is that it encourages specialization, and creates room for concentration, and enhances productivity. It helps to trace product flows, stimulate value addition, and enhances the relationship between the actors in the chain when the chain works effectively without breakage. Agriculture value chain guarantees markets of commodities which eliminates waste and reduces cost incurred in looking for the 
market of agricultural commodities by the farmers. Girabi and Mwakaje (2013) defined agricultural productivity as the ratio of output to input. A farmer is more productive if he uses the same amount of input as another farmer and produces more quantity of output, ceteris paribus.

\subsection{Segmentation Practice in Agriculture}

Segmentation in agriculture has different meaning depending on the author's approach. It may mean divisions between smallholder subsistence non-commercial farmers; small holder commercial farmers in unorganized value chains; and smallholder commercial farmers in organized value chains (Christen \& Anderson, 2013). Christen and Anderson (2013) classified the non-commercial farmers as those who practice agriculture to meet their daily needs, and mainly grow staples. The commercial smallholder farmers in loose value chains are those who grow mixture of staple crops and some high valued crops like sugar and tea. The smallholder commercial farmers in organized value chain are those whose main crops are in value chain.

The definition of agriculture segmentation given by Brent and Akridge (1999) is however more encompassing than that of Christen and Anderson. They defined segmentation in agriculture according to the type of crops, management style, farm size and location. This definition is similar to that given by World Bank (2010). According to the World Bank, segmentation in agriculture is the grouping of farm households according to their enterprise in such a way that the same solution and intervention can be applied. On the other hand, Anderson, Marita, and Musiime (2016) see segmentation in agriculture in terms of the scale and intention of the household in agricultural activity.

From the above definitions, especially those given by World Bank (2010) and Brent and Akridge (1999) a farm household is segmented in agricultural practice if she is concentrated in the production of only one type of crop or engages in one farm operation which she feels she has comparative advantage. Segmentation in agriculture falls within the value chain strategy. As part of the value chain, it is seen as an engine to enhance productivity in agriculture because allowing a household to concentrate on only one crop or farm activity will bring specialization. Supporting segmentation in agriculture practice, World Bank (2010) argues that it is necessary in agricultural finance because it aids the design of insurance policy to mitigate the inherent risk in the sector.

Segmentation in agricultural practice is low in Nigeria as the average small holder farmer grows more than 5 different crops at a time (Anderson, Marita, Musiime, \& Thiam, 2017). Farmers undertake to grow many crops at a time as a means of income diversification and risk minimization. For example, for a farmer growing rice, cassava and maize, an outbreak of disease that affects maize leaves the farmer falling back on cassava and rice for some revenue in that year. That is to say, when one crop fails, a farmer will not lose out entirely in that year. It is the major advantage of the multiple farming practice. However, while the practice is good for risk mitigation, it may not be a good practice when the interest of the state is to increase productivity because it does not give the farmer time to plan.

Kahan (2013) sees segmentation as very essential in planning in farm operation because it enables the farmer to know the best time to start production so as to achieve the highest yield. According to him, through learning by doing, a rice farmer who is not in an irrigated area knows when to start his cropping so that he will not be caught up with adverse weather. A vegetable farmer can target his cultivation according to the demand of the market since he knows when the demand will be high, while the poultry farmer knows when to start breeding his chicks so as to meet the peak of the season. However, the argument of Ye and Pan (2016) is that smallholder farmers that grow different crops in a farm will be more productive because they have wide range of output to harvest.

The commercial agriculture programme financed in Nigeria by the World Bank since 2009 was directed towards encouraging agricultural segmentation as the means of achieving higher productivity among the farmers. Since this shift in agricultural practice in Nigeria, research has not been undertaken to find out the effect of the segmentation practice on farmers' productivity in Nigeria. We have tried to fill this gap in literature with a focus on the poultry sub-sector. The poultry sub-sector was chosen because of the recent ban on importation of chicken products and the growing number of people in the farm business. Moreover, data are always available in every poultry farm which researchers can access.

\section{Materials and Method}

\subsection{Area of Study}

The study was done in South-East of Nigeria and Enugu state in particular. Enugu state is one of the 5 sates selected as a pilot state in Nigeria for segmentation practice in agriculture through the Commercial Agriculture Programme introduced in the country in 2009. The state has a projected population of 4.27 million in 2016 (National Bureau of Statistics, 2016). The state is made up of 17 local governments. Majority of the citizens are in agriculture and small-scale farm holding dominates.

\subsection{Sampling Procedure}

Enugu state was purposely selected as the study area for two important reasons. Number one, it is one of the five pilot states chosen for the agricultural segmentation policy. Secondly, the state has large number of registered poultry farmers who are in segmented as well as multiple poultry farming practice where data can be generated without difficulty. The sampling covered all the 17 local government areas in the state in the areas of poultry farming. The survey covered 171 poultry farmers who were randomly selected from egg, broiler and cockerel production. Out of this number, data from 142 farm samples were used in the analysis and 29 were dropped because of inconsistent information.

\subsection{The Model}

The multivariate analysis is preferred in segmentation agriculture because it allows the inclusion of many independent variables and minimizes the omission of important ones that may have explanatory powers in agricultural productivity. In order to assess the effect of segmentation on farmers' productivity, we combined the 
farmers who concentrated in one poultry (egg production) activity and those who are in more than one activity in poultry (egg, broiler and cockerel production)-: thus,

where $\mathrm{Y}=$ yield that measures productivity

$$
\mathcal{Y}_{i}=f\left(X_{i}\right)
$$

$\mathrm{X}=$ factors that affect productivity

$\mathrm{i}=$ individual farm households $(\mathrm{i}=1,2 \ldots \ldots \mathrm{n}$, where $\mathrm{N}=142$ )

For estimation purposes, Equation 1 can be specified as-:

$$
\Upsilon_{i}=\alpha_{i}+\beta_{i} x_{i}+e_{i}
$$

where

$\mathrm{Y}=$ average number of eggs produced per bird in a farm

$\alpha=$ intercept

$\beta=$ Coefficient

$\chi=$ independent variables that affect egg yield

$\varepsilon=$ error term

$\mathrm{i}=$ individual household

Or Equation 1 can be transformed as shown below-

where

$$
\Upsilon_{i}=\alpha_{i}+\beta_{1} \text { scale }_{i}+\beta_{2} e d_{i}+\beta_{s} \exp _{i}+\beta_{t} \text { seg }_{i}+\beta_{5} \text { sex }_{i}+\mu_{i}
$$

$\mathrm{Y}=$ average number of eggs produced per bird in farm $\mathrm{i}$ in a day,

Scale $=$ farm size which measures the number of birds in farm $\mathrm{i}$,

$\mathrm{Ed}=$ education level of the farm manager

$\mathrm{Exp}=$ experience of the farm manager

$\mathrm{Seg}=$ concentration level of the farm (takes the value 1 when a farmer is in egg production only, 2 when the farmer is in both egg and broiler production, and 3 when the farmer is in egg, broiler and cockerel production),

$\mathrm{Sex}=$ sex of the farm manager (takes value 1 if male and $\mathrm{o}$ when female).

$\alpha$ is the intercept, $\beta 1-\beta_{5}$ are the coefficients of the explanatory variables and $\mu$ is the error.

\section{Result}

Result of the regression analysis is presented in Table 1 below. As an analysis done with primary data, it is not important to carry out diagnostic test as required in time series data.

Table-1. Regression result (Dependent Variable: egg yield)

\begin{tabular}{c|c|c|c|c}
\hline Variable & Coefficient & Std error & $\mathbf{t}$ & $\mathbf{p}>/ \mathbf{t} /$ \\
\hline Scale & 0.0001033 & 0.000012 & 8.61 & 0.000 \\
\hline Ed & 0.787262 & 0.0748034 & 1.05 & 0.294 \\
\hline Sex & 0.0786954 & 0.0922409 & 0.85 & 0.395 \\
\hline Seg & 0.5462244 & 0.1790813 & 3.05 & 0.003 \\
\hline Exp & 0.0150242 & 0.0086749 & 1.73 & 0.086 \\
\hline Const & 2.244965 & 0.2285845 & 9.82 & 0.000 \\
\hline $\mathrm{R}^{2}$ & 0.49 & & & \\
\hline
\end{tabular}

Table 1 is the presentation of the result of the analysis from the farm level survey in Nigeria, using poultry farms as the case study. The most important thing scholars consider in econometric analysis is the sign of the coefficient of the variables in a model. Looking at the sign of the coefficients, all the variables appeared with the expected sign except segmentation. In econometric analysis, $\mathrm{R}^{2}$ is used to measure the explanatory power of a model. The value of the $\mathrm{R}^{2}$ shows that the explanatory variables included in the model explained approximately $50 \%$ of the variations in the productivity of the farms. It is a high explanatory power considering the fact in crosssectional analysis, the $\mathrm{R}^{2}$ is always low.

\section{Discussion of Finding}

What we tried to find out is if segmentation practice introduced in Nigeria through commercial agriculture programme is a solution to low agricultural productivity. In the study undertaken in poultry sub-sector of agriculture, we undertook 3 different classes of farmers. One group is in egg production. The second group is in egg and broiler production and the third group is in egg, broiler and cockerel production. Average number of eggs per day per bird was used as the measure of productivity of a farmer.

As shown in table 1, segmentation has positive coefficient. The variable is also significant, which means that the type of farm practice in poultry sub-sector is an important determinant of productivity in the sector. The interpretation of the positive sign of the coefficient is simple. In the sample used in the study, some farmers specialized in egg production only; the second group specialized in egg and broiler production while the third group of farmers specialized in egg, broiler and cockerel production. From the result in Table 1, farmers who specialized in only egg production have lower yield of egg per bird than the farmers who are in egg and broiler production simultaneously. In the same vein, farmers who are in egg and broiler production have lower yield of egg per bird per day than the farmers who are in egg, broiler and cockerel production at the same time. The finding suggests that a poultry farmer who specializes in only egg production will be less productive than the one who is engaged in egg and broiler production at the same time.

The other two variables that have significant effect on productivity of poultry farmers in Nigeria are the farm scale and experience of the manager. Farm size is positive and significant at $1 \%$ level. It suggests that the bigger the size of the poultry farm, the higher the productivity of the farmer. That implies that farmers who have a greater number of birds have higher average yield of egg per bird than the farmers who have fewer number of birds. 
Similarly, experience is positive and significant at $10 \%$ level, revealing that the more the experience of the manager, the higher the productivity. Therefore, in poultry farming, experience counts.

\section{Conclusion}

Segmentation in agriculture practice is a new strategy in agricultural business so as to overcome the problem of low productivity in agriculture in Nigeria. The practice has support from World Bank in five farm areas, namely: poultry, rice, maize, pineapple and cashew. Evidence from analysis of data generated from farm household survey in the poultry sub-sector in Nigeria suggests that the farmers that specialized in a single poultry practice are less productive than those in two or more practice. For policy intervention in poultry sub-sector in Nigeria, farmers need assistance to access credit to be able to go into large scale poultry farming. Farmers should be assisted to go into multiple poultry farming because they will do better than specializing in only one poultry business.

\section{References}

Anderson, J., Marita, C., \& Musiime, D. (2016). National survey and segmentation of smallholder households in Tanzania understanding their demand for financial, agricultural, and digital solutions. Consultative Group to Assist the Poor (CGAP) Working Paper 2016, 1818 H Street NW MSN F3K-306 Washington, DC 20433.

Anderson, J., Marita, C., Musiime, D., \& Thiam, M. (2017). National survey and segmentation of smallholder households in Nigeria understanding their demand for financial, agricultural, and digital solutions. Consultative Group to Assist the Poor (CGAP) Working Paper 2017, Consultative Group to Assist the Poor (CGAP), 1818 H Street NW MSN F3K-306 Washington, DC 20433.

Awotide, B. A., Abdoulaye, T., Alene, A., \& Manyong, V. M. (2015). Impact of access to credit on agricultural productivity: Evidence from smallholder cassava farmers in Nigeria. Paper presented at the International Conference of Agricultural Economists (ICAE), Milan, Italy

Awotide, B. A., Diagne, A., \& Omonona, B. T. (2012). Impact of improved agricultural technology adoption on sustainable rice productivity and rural farmers' welfare in Nigeria: A local average treatment effect (LATE) technique. Paper presented at the African Economic Conference, Kigali, Rwanda.

Bassey, N. E., Edet, M. E., \& Agom, D. I. (2016). Impact of institutional funding on agricultural labour productivity in Nigeria: A cointegration approach. Agricultural Science Research Journal, 6(2), 49-55.

Brent, G. A., \& Akridge, J. T. (1999). Segmenting the commercial producer marketplace for agricultural inputs. The International Food and Agribusiness Management Review, 2(2), 145-163.Available at: https://doi.org/10.1016/s1096-7508(00)00023-9.

Christen, R. P., \& Anderson, J. (2013). Segmentation of smallholder households: Meeting the range of financial needs in agricultural families. CGAP Focus Note No. 85.

Federal Ministry of Agriculture Water Resources and Rural Development. (2009). Agricultural extension transformation agenda- FMARD. Abuja: Federal Ministry of Agriculture and Rural Development, Abuja, Nigeria.

Food and Agricultural Organization (FAO). (2017a). Global yield gap food and agricultural organization o0153 Rome, Italy. Retrieved from: http://www.yieldgap.org/glossary.

Food and Agricultural Organization (FAO). (2017b). Food balance sheet: Livestock primary food and africultural organisation, FAOSTAT O0153 Rome, Italy

Girabi, F., \& Mwakaje, A. E. G. (2013). Impact of microfinance on smallholder farm productivity in Tanzania: The case of Iramba district. Asian Economic and Financial Review, 3(2), 227-242

Kahan, D. (2013). Managing risk in farming: Farm management extension guide 3 food and agricultural organization. Rome. Retrieved from: http://www.fao.org/uploads/media/3-ManagingRiskInternLores.pdf.

National Bureau of Statistics. (2016). Projected population of nigeria by state 2011 - 2015. National Bureau of Statistics Headquarters, Abuja Nigeria. Retrieved from: www.nigerianstat.gov.ng.

Okike, I. (2010). A dairy value chain approach to approach implementation - ideas and key constructs. Paper presented at the Workshop of the Project Facilitation Team of the Commercial Agriculture Development Project (CADP), Ilorin, Nigeria, 19-2 1 July 2010.

Smith, A. (1776). An inquiry into the nature and causes of the wealth of nations, Wealth of Nations Book, in Soares S.M ed (2007)Third Edition Wealth of Nations Book New York.

World Bank. (2010). Agricultural insurance in latin America: Developing the market. Developing the Market. Report no. 61963-LAC.

World Bank. (2016). Population prospects, united nations population divisions. Population Division, 2 United Nations Plaza, Room DC21950 New York, USA.

Ye, J., \& Pan, I. (2016). Concepts and realities of family farming in Asia and the pacific. International Policy Centre for Inclusive Growth (IPCIG) Working Paper No. 139. 